\title{
Fine-Mapping of the Powdery Mildew Resistance Gene mlxbd in the Common Wheat Landrace Xiaobaidong
}

\author{
Yanlong Jin, ${ }^{1}$ Fei Xue, ${ }^{1, \dagger}$ Yilin Zhou, ${ }^{2}$ Xiayu Duan, ${ }^{2}$ Jinghuang Hu, ${ }^{1}$ Yanjun Li, ${ }^{1}$ Huaguo Zhu, ${ }^{1}$ and Jie Sun ${ }^{1}$ \\ ${ }^{1}$ College of Agronomy, Shihezi University, The Key Laboratory of Oasis Eco-agriculture, Xinjiang Production and Construction \\ Group, Shihezi University, Shihezi 832003, China \\ ${ }^{2}$ State Key Laboratory of Biology for Plant Diseases and Insect Pests, Institute of Plant Protection, Chinese Academy of Agri- \\ cultural Sciences, Beijing 100193, China
}

\begin{abstract}
Powdery mildew, which is caused by Blumeria graminis f. sp. tritici $(B g t)$, is a disease of wheat worldwide. Xiaobaidong is a Chinese wheat landrace, which still maintains good resistance against powdery mildew. To obtain more genetic markers closely linked to the powdery mildew resistance gene $m l x b d$ and narrow the candidate region for its isolation, new simple sequence repeats and cross intron-spanning markers were

distances of $0.4 \mathrm{cM}$ and $0.3 \mathrm{cM}$, respectively. The resistance locus was mapped to a $63.40 \mathrm{~kb}$ and $0.29 \mathrm{Mb}$ region of the Chinese Spring genome and Zavitan genome, respectively. The linked markers of $m l x b d$ could be used as diagnostic markers for mlxbd. The linked molecular markers and delineated genomic region in the sequenced Chinese Spring genome will assist the future map-based cloning of $m l x b d$.
\end{abstract} designed based on the genome sequence of Triticum aestivum cultivar Chinese Spring chromosome 7BL. The flanking markers 7BLSSR 49 and WGGC5746 were found to be tightly linked to $m l x b d$ at genetic
Keywords: comparative genomics, fine mapping, mlxbd, molecular markers, powdery mildew, resistance genes, wheat
Wheat is one of the most important food crops in the world and provides about $20 \%$ of the food consumed by humans. However, wheat production faces many threats from pathogens, among which Blumeria graminis (DC.) Speer f. sp. tritici emend. É. J. Marchal (Bgt) causes powdery mildew, one of the most harmful diseases. The rapid evolution of the pathogen and hybridization among different Bgt strains generate novel pathotypes (Menardo et al. 2016), resulting in the rapid loss of resistance effectiveness in wheat cultivars. Therefore, identifying effective and durable resistance resources is necessary for breeding resistant cultivars. The development of wheat cultivars with resistance genes is the most economical, effective, and environmentally safe strategy for controlling powdery mildew.

To date, $>70$ formally named $P m$ resistance genes at 61 loci have been reported $(P m 1$ to $P m 65, P m 18=P m 1 c, P m 22=P m 1 e, P m 23=$ $P m 4 c$, and $P m 31=P m 21$ ) (Hao et al. 2008; Hsam et al. 1998; Li et al. 2019; Singrün et al. 2003; Xie et al. 2011). Of these genes, $P m 2 c$ (Xu et al. 2015), Pm5d (Nematollahi et al. 2008), Pm5e (Huang et al. 2003), Pm24a (Huang et al. 2000a), Pm24b (Xue et al. 2012b), Pm47 (Xiao et al. 2013), Pm59 (Tan et al. 2018), Pm61 (Sun et al. 2018), and Pm63 (Tan et al. 2019) were derived from Chinese wheat landraces.

Besides the multiallelic Pm5 (Pm5a to Pm5e) locus, 10 temporarily designated $P m$ genes were located on chromosome 7BL. Using bulked segregant analysis (BSA), comparative genomics, 90K microarray analysis, and transcriptome sequencing (RNA-Seq) methods, PmTm4 (Xie et al. 2017), PmHYM (Fu et al. 2017),

${ }^{\dagger}$ Corresponding author: F. Xue; xuefei2011@gmail.com

Funding: Financial support for this research was provided by the National Natural Science Foundation of China grant 31360335.

*The $\boldsymbol{e}$-Xtra logo stands for "electronic extra" and indicates that three supplementary figures and five supplementary tables are published online.

The author(s) declare no conflict of interest.

Accepted for publication 25 October 2019.

(C) 2020 The American Phytopathological Society
PmBYYT (Xu et al. 2018a), PmSGD (Xu et al. 2018b), and pmDHT (Qie et al. 2019) have available high-resolution genetic maps. However, the linkage maps of mljy and mlsy (Huang et al. 2002), PmH (Zhou et al. 2005), mlmz (Zhai et al. 2008), and $m l x b d$ (Xue et al. 2009 b) are not of high resolution.

For many years, Xiaobaidong has maintained a constant level of resistance to powdery mildew. The single recessive gene $m l x b d$ is located on the distal bin 7BL-10 (Bin 0.78 to 1.00). So far, the closest flanking markers of $m l x b d$ were Xgwm1267 and Xgwm577, with genetic distances of $8.2 \mathrm{cM}$ and $3.5 \mathrm{cM}$, respectively (Xue et al. 2009b).

The Chinese Spring reference genome (IWGSC RefSeq version 1.0 database) was used to fine map powdery mildew resistance genes $P m 4 b$ (Wu et al. 2018), Pm4e (Ullah et al. 2018), Pm63 (Tan et al. 2019), and Pm64 (Zhang et al. 2019). In this study, we used the Chinese Spring reference genome to develop markers and screened previously reported markers to construct a saturated linkage map of $m l x b d$. Fine mapping of $m l x b d$ could contribute to the comparison of different genes at this locus and the map-based cloning of the Pm5 locus.

\section{Materials and Methods}

Plant materials. Xiaobaidong is a common wheat landrace originating from Xinjiang province, China, which shows a wide spectrum of resistance to powdery mildew and harbors the gene $m l x b d$. Chancellor (CC), a common wheat cultivar without resistance, was used as the susceptible parent in the present study. A total of 190 $\mathrm{F}_{2}$ progenies derived from the cross of Xiaobaidong and $\mathrm{CC}$ were used to map the powdery mildew resistance gene $m l x b d$. One susceptible cultivar CC and 11 resistant cultivars and lines with known $\mathrm{Pm}$ resistance genes were used to validate markers flanking $m l x b d$ for marker-assisted selection. Seeds of the CC, Xiaobaidong (with $m l x b d$ ), Mazhamai (with $m l m z$ ), Bensanyuehuang (with $P m B S Y H$ ), Shangeda (with $P m S G D$ ), Youbailan (with $P m Y B L$ ), Baiyouyantiao (with $P m B Y Y T$ ), Hongquanmang (with $P m H$ ), Mangmai (with mlmm), Hope/8CC (with Pm5a), Aquila (with Pm5b), and Fuzhuang 30 (with $P m 5 e$ ) were provided by the Institute of Plant Protection, Chinese Academy of Agricultural Sciences, Beijing.

Evaluation of powdery mildew reactions. The Bgt isolate E09 was kindly provided by the Institute of Plant Protection, Chinese Academy of Agricultural Sciences, Beijing, and was used for resistance tests in this study. Plants were inoculated at the two-leaf stage 
Table 1. Genetic analysis of the powdery mildew resistance gene $m l x b d^{\mathrm{a}}$

\begin{tabular}{lcccccc}
\hline $\begin{array}{l}\text { Mapping } \\
\text { population }\end{array}$ & Resistance & Susceptible & Ratio & Total & $\boldsymbol{\chi}^{\mathbf{2}}$ & $\begin{array}{c}\boldsymbol{P} \\
\text { value }\end{array}$ \\
\hline Xiaobaidong & 10 & - & - & 10 & - & - \\
CC & - & 10 & - & 10 & - & - \\
CC/Xiaobaidong & - & 20 & - & 20 & - & - \\
$\quad F_{1}$ & & 136 & $1: 3$ & 190 & 1.19 & 0.28 \\
CC/Xiaobaidong & 54 & & & & & \\
$\mathrm{~F}_{2}$ & & & & & &
\end{tabular}

via the dusting method (Xue et al. 2012a). In addition, the phenotypes of some $\mathrm{F}_{2}$ plants were confirmed by phenotyping their corresponding $\mathrm{F}_{2: 3}$ lines. Crops were grown at 16 to $20^{\circ} \mathrm{C}$ in the greenhouse and covered with a plastic film during cultivation, to avoid contamination by other pathogens.

Powdery mildew reactions were evaluated when disease symptoms of CC were fully developed. The infection types (ITs) of powdery mildew on the leaves were recorded on a scale of 0 to 4 , in which 0 is immune, with no reaction on the entirety of the plant; " 0 ;" is nearly immune, with hypersensitive necrotic flecks on the leaves only; 1 represents a highly resistant reaction with minute $B g t$ colonies

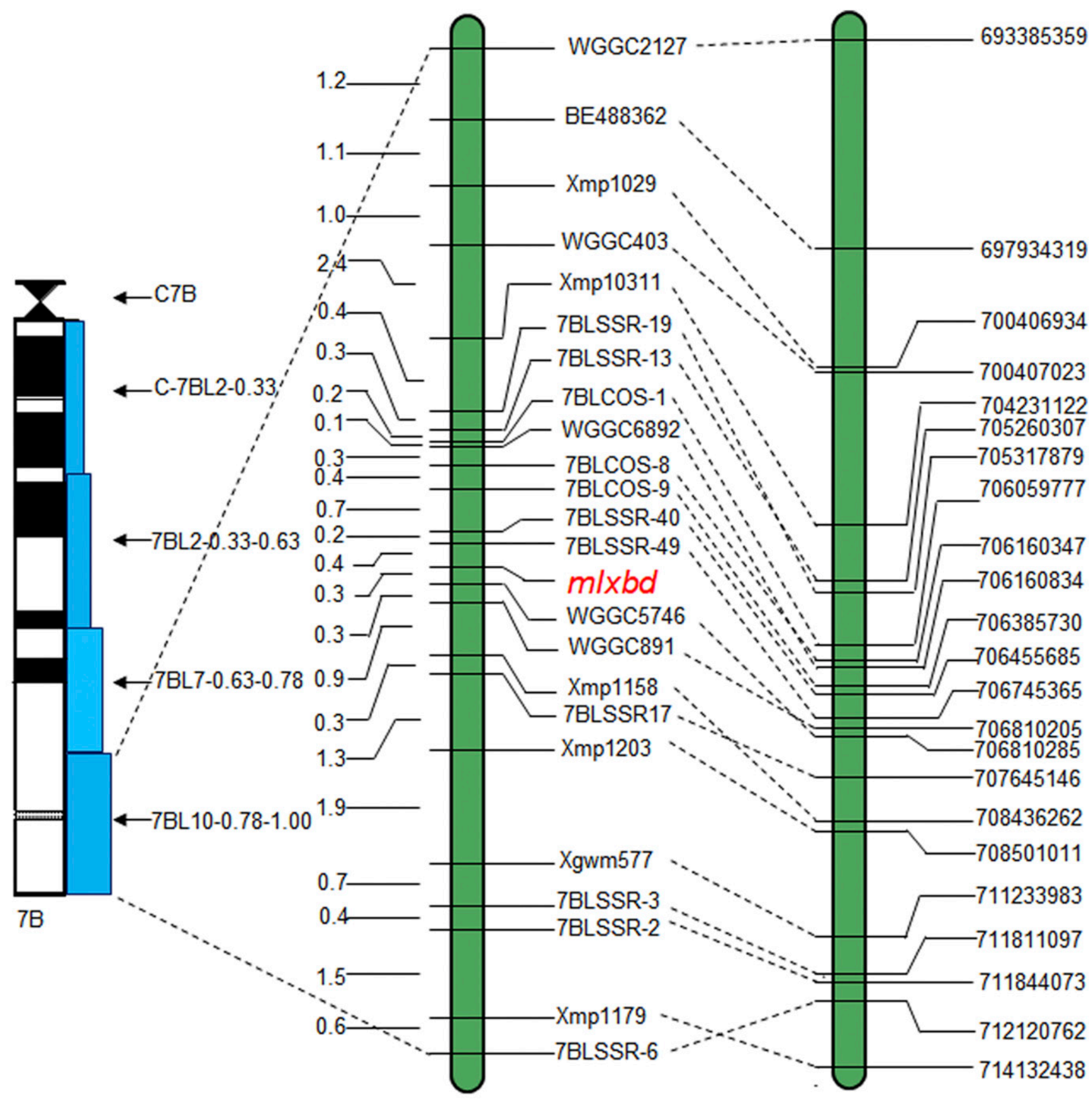

Physical map

A
Genetic linkage map of $m l x b d$

B
Corresponding markers position in Chinese Spring Chr. 7BL genome

Fig. 1. Molecular mapping of the $m / x b d$ locus in the $\mathrm{F}_{2}$ populations derived from Xiaobaidong $\times \mathrm{CC}$, and alignment of the markers on the mlxbd maps to the Triticum aestivum cultivar Chinese Spring chromosome (Chr.) 7BL genomic DNA sequence database. A, Schematic diagram of the physical position of $m / x b d$ on Chr. 7BL, B, genetic linkage map, and $\mathbf{C}$, corresponding position of markers in the Chinese Spring Chr. 7BL genome. 
on the leaves, generally $<1 \mathrm{~mm}$, with few conidia; 2 represents a moderately resistant reaction, with colonies $<1 \mathrm{~mm}$ with some conidia; 3 is a moderately susceptible reaction, with abundant conidia but with colonies not joining together; and 4 is a highly susceptible reaction that is similar to grade 3, except that the Bgt colonies mostly joined together (Sheng 1988). These groups were further pooled into two larger groups: resistant ( $\mathrm{R}, \mathrm{IT}=0$ to 2$)$ and susceptible $(\mathrm{S}, \mathrm{IT}=$ 3 and 4).

Genomic DNA extraction. After the evaluation of powdery mildew reactions, the genomic DNA of the $F_{2}$ segregating populations and parents was extracted via the cetyltrimethylammonium bromide method (Saghai-Maroof et al. 1984), with the slight modification of using one chloroform extraction step. The amount of DNA in the samples was estimated with a spectrophotometer, and then $1 \%$ agarose gel electrophoresis was used to estimate DNA quality.

Molecular marker development. Based on the information on the GrainGenes website (https://wheat.pw.usda.gov/GG2/ index.shtml) and from previous studies (Fu et al. 2017; Xie et al. 2017; Xue et al. 2009b), primers for the 7BL chromosomal region of the $m l x b d$ locus and its nearby regions were synthesized and used to screen these regions for polymorphism (Supplementary Table S1).

Table 2. Marker sequences closely linked to $m l x b d$

\begin{tabular}{|c|c|c|c|c|c|}
\hline No. & Marker name & Forward primer $\left(5^{\prime} \rightarrow 3^{\prime}\right)$ & Reverse primer $\left(5^{\prime} \rightarrow 3^{\prime}\right)$ & Annealing temperature $\left({ }^{\circ} \mathrm{C}\right)$ & Dominance \\
\hline 1 & WGGC2127 & ССААСТССАССТТССТСТТ & CCAAACCCTAACCCTGATT & 56 & Dominance \\
\hline 2 & BE488362 & TGCTCTTGCTCTTGTGGTC & CATACGAAGGGCATAACACC & 55 & Dominance \\
\hline 3 & Хтmp1029 & ТСТСТСТСАСТGТССТАСАА & GAATAAGAACCCTCCAAAG & 54 & Codominance \\
\hline 4 & $W G G C 403$ & CGGAAAGCGTCAAGTAAA & GAGCTTGGGACATTTCAGT & 52 & Dominance \\
\hline 5 & Хтр10311 & СССТCTCTGTCACTTCTTCT & CCTGAGTCCCGCACTA & 52 & Codominance \\
\hline 6 & $7 B L S S R-19$ & TGGGTTTCGCATTTCAAGTGTT & GGGCATGTCTGTCGAGTAAGAAT & 54 & Dominance \\
\hline 7 & $7 B L S S R-13$ & CGGAAGGCGGATAAAAGGGT & GCCTATCCTTGCGTCTTGGT & 57 & Codominance \\
\hline 8 & $7 B L C O S-1$ & AAAGCCATGAAGCCGAAAGC & TGGCAGTGCAAATGTAACGC & 55 & Codominance \\
\hline 9 & WGGC6892 & TGCTGTCAAGATGGCAAACT & TGCAGGCCACTATGATTTGTG & 53 & Codominance \\
\hline 10 & $7 B L C O S-8$ & GAGATCCTGTCGAACAAGCAG & TGCCTTCATCCTTCTACTGAGC & 58 & Codominance \\
\hline 11 & $7 B L C O S-9$ & AAGCTCCTCATCCACGACTAC & TCTTGTCGTGGATGAATGCC & 55 & Codominance \\
\hline 12 & $7 B L S S R-40$ & CTCGCTGTGTGCGTGTGT & ATAGTACGTGGTGGCATCTTA & 54 & Codominance \\
\hline 13 & $7 B L S S R-49$ & AGCCGTGTACAACTCTGCTG & AGGGCACTAACCAATCCAGT & 55 & Codominance \\
\hline 14 & WGGC5746 & TTCAGCCGTCCATCTCCTTT & GGAGAGATCAACTGCAACGAC & 55 & Codominance \\
\hline 15 & WGGC891 & CTCTGGGTGGACCTGATGAT & GCGGAGATTCAGAATTTTCAT & 52 & Codominance \\
\hline 16 & Xmp1158 & AGCAAATCCTTCTGCGAG & ATGTATGTGGTGGTCTGGC & 54 & Codominance \\
\hline 17 & $7 B L S S R-17$ & CGCCGCTTATTTTGTGCACT & GCCCATAGTCGTGCGCTAT & 55 & Codominance \\
\hline 18 & Xmp1203 & CATCTTGGGCATAGGCAA & ATCTCTCTCTCTCTCAGGTCGG & 54 & Dominance \\
\hline 19 & Xgwm577 & ATGGCATAATTTGGTGAAATTG & TGTTTCAAGCCCAACTTCTATT & 52 & Dominance \\
\hline 20 & $7 B L S S R-3$ & CACTCATGCTCCTTGGTCGT & CCTCCTCGTCGTATCTTGGC & 57 & Codominance \\
\hline 21 & $7 B L S S R-2$ & CACTCATGCTCCTTGGTCGT & CCGCTTTCCCTGAGTTCACT & 57 & Codominance \\
\hline 22 & Хmp1179 & TCCCTGATTAGTTGCCCGA & AACGAGATGGAATGGAGGC & 58 & Codominance \\
\hline 23 & $7 B L S S R-6$ & TGCGCGTCACAAACAAAGTT & GCCGGCCGATTAAAAACGTA & 53 & Dominance \\
\hline
\end{tabular}

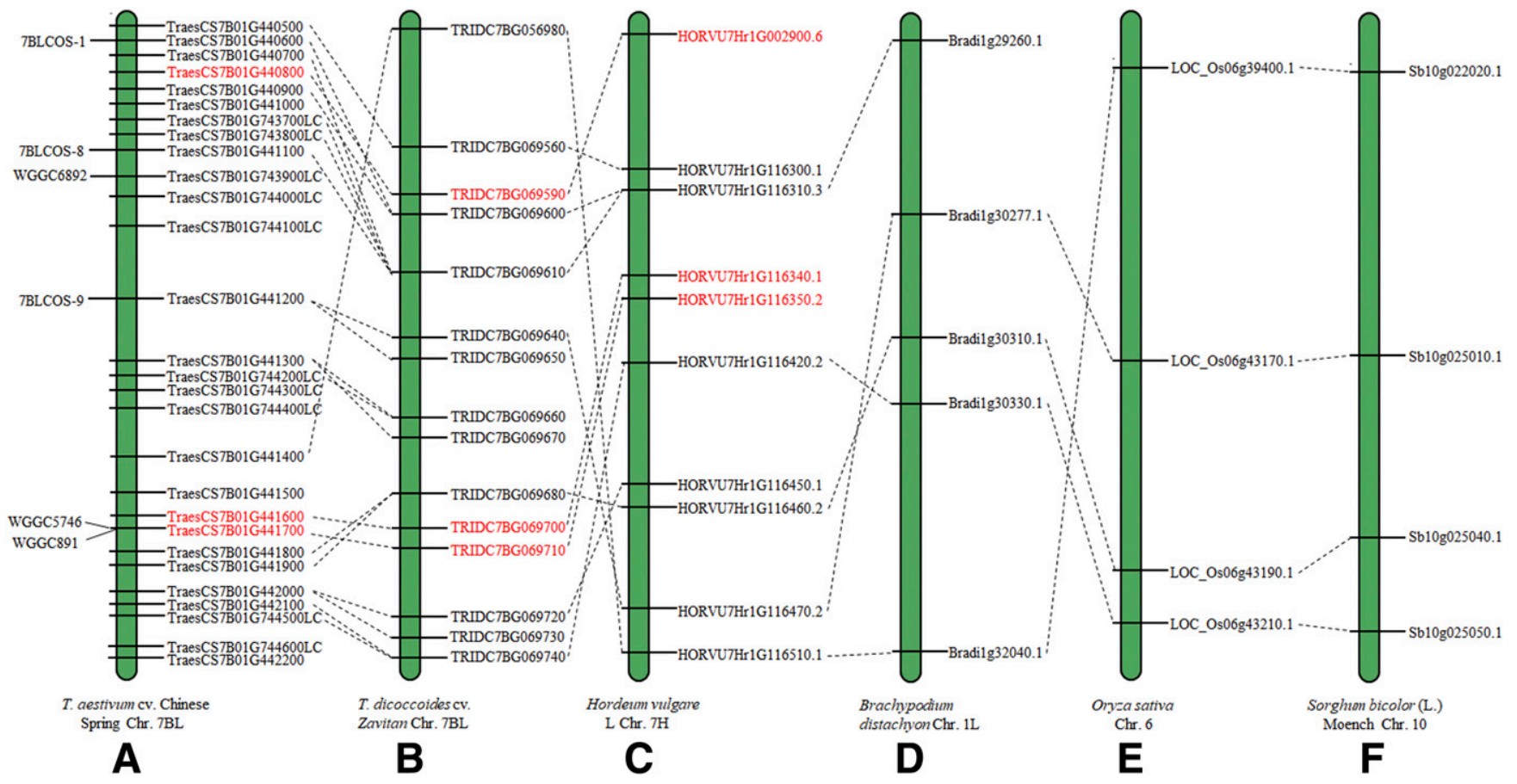

Fig. 2. Comparative genomic mapping of the powdery mildew resistance gene $m / x b d$. A, Schematic diagram of $m / x b d$ in the Triticum aestivum cultivar Chinese Spring chromosome (Chr.) 7BL genome, B, synteny of genes among Triticum dicoccoides cultivar Zavitan Chr. 7BL, C, Hordeum vulgare L Chr. 7H, D, Brachypodium distachyon Chr. 1L, E, Oryza sativa Chr. 6, and F, Sorghum bicolor Moench Chr. 10. The collinear genes and resistance-related genes found among Chinese Spring, wild emmer, barley, Brachypodium, rice, and sorghum in the genomic interval corresponding to mlxbd are shown. Orthologous genes are linked by dashed lines, and resistance-related genes are shown in red. 
To narrow down the location of the $m l x b d$, the genomic sequences of the corresponding region of Chinese Spring (http:// www.wheatgenome.org/Projects/IWGSC-Bread-Wheat-Projects/ Sequencing/IWGSC-Chromosome-Survey-Sequencing/Results) were used to develop PCR-based markers for mapping and genotyping. Primers for simple sequence repeats (SSRs) and cross intron-spanning markers were designed with the online resources PrimerServer (http:// 202.194.139.32/PrimerServer/) (Zhu et al. 2017) and Batchprimer 3 (https://probes.pw.usda.gov/batchprimer3/). The information on the primers used is shown in Supplementary Tables S2, S3, and
S4. The markers showing polymorphisms between the resistant and susceptible parents and between the two bulks were used to genotype the $\mathrm{F}_{2}$ population. PCR was then performed in a total volume of $20 \mu \mathrm{l}$ containing $2.0 \mu \mathrm{l}$ of $10 \times$ Taq PCR buffer, $1.6 \mu \mathrm{l}$ of dNTPs $(2.5 \mathrm{mM}), 1.0 \mu \mathrm{l}$ of each primer $(10 \mu \mathrm{M}), 0.2 \mu \mathrm{l}$ of Taq polymerase ( $5 \mathrm{U} / \mu \mathrm{l}), 2.0 \mu \mathrm{l}$ of genomic DNA (150 to $250 \mathrm{ng} / \mu \mathrm{l}$ ), and $12.2 \mu \mathrm{l}$ of double-distilled $\mathrm{H}_{2} \mathrm{O}$. The PCR amplifications were carried out with the following steps: denaturation for $3 \mathrm{~min}$ at $94^{\circ} \mathrm{C} ; 32$ cycles of denaturation for $30 \mathrm{~s}$ at $94^{\circ} \mathrm{C}$, annealing for $30 \mathrm{~s}$ at 48 to $65^{\circ} \mathrm{C}$ (depending on the annealing temperature of the primer pairs being used), and

Table 3. Gene prediction and annotation of the genetic interval flanking mlxbd

\begin{tabular}{|c|c|c|}
\hline \multirow[b]{2}{*}{ No. } & \multicolumn{2}{|r|}{ Chinese Spring chromosome 7BL } \\
\hline & Gene name & Gene functional annotation ${ }^{a}$ \\
\hline 1 & TraesCS7B01G440500 & Pectin lyase-like superfamily protein \\
\hline 2 & TraesCS7B01G440600 & Cytochrome P450 \\
\hline 3 & TraesCS7B01G440700 & Cytochrome P450 \\
\hline 4 & TraesCS7B01G440800 & Disease resistance protein (TIR-NBS-LRR class) family ${ }^{b}$ \\
\hline 5 & TraesCS7B01G440900 & Cytochrome P450 \\
\hline 6 & TraesCS7B01G441000 & Transmembrane protein, putative (DUF247) \\
\hline 7 & TraesCS7B01G743700LC & Cytochrome P450 \\
\hline 8 & TraesCS7B01G743800LC & Cytochrome P450 \\
\hline 9 & TraesCS7B01G441100 & Cytochrome P450 \\
\hline 10 & TraesCS7B01G743900LC & Alanine-transfer RNA ligase \\
\hline 11 & TraesCS7B01G744000LC & Retrotransposon protein, putative, LINE subclass \\
\hline 12 & TraesCS7B01G744100LC & RNA-directed DNA polymerase (reverse transcription)-related family protein \\
\hline 13 & TraesCS7B01G441200 & Receptor protein kinase-like protein \\
\hline 14 & TraesCS7B01G441300 & Phosphoribosylamine-glycine ligase \\
\hline 15 & TraesCS7B01G744200LC & Receptor tyrosine-protein kinase erbB-3 \\
\hline 16 & TraesCS7B01G744300LC & Protein FAR1-related sequence 5 \\
\hline 17 & TraesCS7B01G744400LC & RNA-directed DNA polymerase (reverse transcription)-related family protein \\
\hline 18 & TraesCS7B01G441400 & ARM repeat superfamily protein \\
\hline 19 & TraesCS7B01G441500 & Fructose-1,6-bisphosphatase class 1 \\
\hline 20 & TraesCS7B01G441600 & NBS-LRR resistance-like protein ${ }^{b}$ \\
\hline 21 & TraesCS7B01G441700 & Disease resistance protein (NBS-LRR class) family ${ }^{\mathrm{b}}$ \\
\hline 22 & TraesCS7B01G441800 & Calcium-dependent lipid-binding domain-containing protein \\
\hline 23 & TraesCS7B01G441900 & Calcium-dependent lipid-binding domain-containing protein \\
\hline 24 & TraesCS7B01G442000 & Germin-like protein \\
\hline 25 & TraesCS7B01G442100 & E3 ubiquitin-protein ligase MARCH6 \\
\hline 26 & TraesCS7B01G744500LC & Elongation factor $\mathrm{P}$ \\
\hline 27 & TraesCS7B01G744600LC & Transfer RNA pseudouridine synthase A \\
\hline 28 & TraesCS7B01G442200 & P-loop containing nucleoside triphosphate hydrolase superfamily protein \\
\hline
\end{tabular}

a TIR, Toll-interleukin-1 receptor; NBS, nucleotide binding site; LRR, leucine rich repeat.

${ }^{\mathrm{b}}$ Resistance-related genes.

Table 4. Linkage markers of $m l x b d$ tested across 10 wheat landraces with known $P m$ resistance genes and the susceptible control cultivar Chancellor (CC, without Pm genes)

\begin{tabular}{|c|c|c|c|c|c|c|c|c|c|c|c|}
\hline \multirow[b]{2}{*}{ No. } & \multirow[b]{2}{*}{$\begin{array}{c}\text { Landraces and Pm } \\
\text { genes }\end{array}$} & \multicolumn{10}{|c|}{ Marker $^{a}$} \\
\hline & & $W G G C 2127$ & BE488362 & Xmp1029 & WGGC403 & Xmp10311 & $\begin{array}{c}\text { 7BLSSR- } \\
19\end{array}$ & $\begin{array}{c}\text { 7BLSSR- } \\
13\end{array}$ & $\begin{array}{c}7 B L C O S- \\
1\end{array}$ & WGGC6892 & $\begin{array}{c}7 B L C O S- \\
8\end{array}$ \\
\hline 1 & Chancellor & $\Delta$ & $\Delta$ & $\Delta$ & $\Delta$ & $\Delta$ & $\Delta$ & $\Delta$ & $\Delta$ & $\Delta$ & $\Delta$ \\
\hline 2 & Hope/CC (Pm5a) & 0 & $\Delta$ & $\bullet$ & 0 & ○ & $\boldsymbol{\Delta}$ & 0 & $\Delta$ & 0 & $\Delta$ \\
\hline 3 & Aquila $(P m 5 b)$ & 0 & 0 & $\Delta$ & $\Delta$ & $\boldsymbol{\Delta}$ & 0 & 0 & 0 & $\Delta$ & $\Delta$ \\
\hline 4 & Fuzhuang $30(P m 5 e)$ & 0 & $\square$ & $\square$ & $\square$ & $\square$ & $\square$ & $\square$ & $\square$ & $\square$ & $\square$ \\
\hline 5 & Xiaobaidong $(m l x b d)$ & $\square$ & $\square$ & $\square$ & $\square$ & $\square$ & $\square$ & $\square$ & $\square$ & $\square$ & $\square$ \\
\hline 6 & Shangeda $(P m S G D)$ & $\square$ & $\square$ & $\square$ & $\square$ & $\square$ & $\square$ & $\square$ & $\square$ & $\square$ & $\square$ \\
\hline 7 & Mangmai $(\mathrm{mlmm})$ & $\square$ & $\square$ & $\square$ & $\square$ & $\square$ & $\square$ & $\square$ & $\square$ & $\square$ & $\square$ \\
\hline 8 & Youbailan $(P m Y B L)$ & 0 & $\Delta$ & $\square$ & $\square$ & $\square$ & $\square$ & $\square$ & $\square$ & $\square$ & $\square$ \\
\hline 9 & $\begin{array}{l}\text { Baiyouyantiao } \\
\quad(P m B Y Y T)\end{array}$ & $\bullet$ & $\Delta$ & $\square$ & $\square$ & $\square$ & $\square$ & $\square$ & $\square$ & $\square$ & $\square$ \\
\hline 10 & Hongquangmang $(P m H)$ & $\bullet$ & $\bullet$ & $\bullet$ & $\bullet$ & $\bullet$ & $\square$ & $\bullet$ & $\bullet$ & $\bullet$ & $\square$ \\
\hline 11 & Mazhamai $(\mathrm{mlmz})$ & 0 & 0 & 0 & 0 & 0 & $\Delta$ & $\Delta$ & 0 & $\square$ & $\square$ \\
\hline 12 & Bensanyuehuang & 0 & 0 & 0 & 0 & 0 & 0 & 0 & 0 & $\square$ & $\square$ \\
\hline
\end{tabular}

(Continued on next page)

\footnotetext{
a $\square$ denotes the same genotype as Xiaobaidong, $\bullet$ indicates that the genotype was different from that of Xiaobaidong, and $\boldsymbol{\Delta}$ denotes the same genotype as Chan-
} cellor. All germplasm resources came from the Institute of Plant Protection, Chinese Academy of Agricultural Sciences. 
extension for $45 \mathrm{~s}$ at $72^{\circ} \mathrm{C}$; and a final extension step for $10 \mathrm{~min}$ at $72^{\circ} \mathrm{C}$. The PCR products were separated on $8 \%$ nondenaturing polyacrylamide gels with $37.5: 1$ ratios of acrylamide to bis-acrylamide, and the banding patterns were visualized with silver staining.

Linkage analysis. The proportions of susceptible and resistant phenotypes in the $F_{2}$ segregating populations after inoculation were counted and then subjected to genetic analysis to test whether they were consistent with the expected ratio, and $\chi^{2}$ tests were conducted to determine the goodness of fit of this comparison. JoinMap 4.0 software was used to calculate the distance between each molecular marker and the $m l x b d$ gene (https://www.kyazma.nl/index.php/JoinMap/), with a logarithm of the odds threshold of 3.0. Software MapDraw version 2.1 was used to construct molecular marker linkage maps of the $m l x b d$ gene (Liu and Meng 2003).

Comparative genomic analysis. The genomic sequences and annotations of wheat, wild emmer, Brachypodium, barley, rice, and sorghum were obtained from the IWGSC (International Wheat Genome Sequencing Consortium) RefSeq version 1.0 database (http:// www.wheatgenome.org/), Zavitan WEWSeq (Wild Emmer Wheat Genome Sequencing Consortium) version 1.0 database (https://wheat. pw.usda.gov/GG3/jbrowse_Zavitan), Brachypodium distachyon version 1.0 database (http://ensembl.gramene.org/Brachypodium_ distachyon/Info/Index), Hordeum vulgare IBSC2017 (International Barley Sequencing Consortium) database, Oryza sativa RGAP (Rice Genome Annotation Project) version 7 database, and Sorghum bicolor MIPS (Munich Information Center for Protein Sequence) version 1.4 database (http://pgsb.helmholtz-muenchen.de/plant/ plantsdb.jsp), respectively. In the present study, the markers closely linked to the $m l x b d$ gene were obtained by screening previous markers, and the candidate region containing $m l x b d$ was identified by aligning the marker sequences against the IWGSC RefSeq version 1.0 database (expected threshold $=1$, nucleotide identity $=100 \%$ ). The best matches in the BLAST output were sought by aligning their sequences to those in the Chinese Spring genome for the comparisons of their collinear relationships (E-value $<1 \times 10^{-10}$ and identity $>80 \%$ ).

\section{Results}

Phenotypic and genetic analyses. When inoculated with Bgt isolate E09, plants of the cultivar Xiaobaidong were highly resistant (IT = 0 and $0 ;$ ), whereas those of CC were highly susceptible $($ IT $=4)$ (Supplementary Fig. S1). All $\mathrm{F}_{1}$ plants were susceptible to the $B g t$ isolate E09 $(\mathrm{IT}=4)$. The $190 \mathrm{~F}_{2}$ progenies segregated into 54 resistant and 136 susceptible individuals, with the segregation ratio consistent with the expected $1: 3$ ratio $\left(\chi^{2}=1.19, P=0.28, d f=1\right)$
(Table 1). These results confirmed that the resistance of Xiaobaidong to $B g t$ isolate E09 was controlled by a single recessive gene $(m l x b d)$ (Xue et al. 2009b).

Fine-mapping of powdery mildew resistance gene $\boldsymbol{m l x b d}$. To obtain more genetic markers closely linked to $m l x b d, 67$ SSR markers of previous reports (Supplementary Table S1) and 21 pairs of newly developed SSR primers (Supplementary Table S2) on chromosome 7BL of the target region were used to screen for markers polymorphic between the Xiaobaidong and CC cultivars, as well as between the resistant and susceptible individuals of the $\mathrm{F}_{2}$ population. Among the polymorphic SSR markers, 19 were linked to $m l x b d$. The two closest-flanking markers to the target gene were WGGC6892 and WGGC5746, with genetic distances of $2.0 \mathrm{cM}$ and $0.3 \mathrm{cM}$, respectively (Fig. 1, Supplementary Fig. S2).

To further delineate the genetic location of $m l x b d, 35$ pairs of SSR primers (Supplementary Table S3) and 22 pairs of cross intronspanning markers (Supplementary Table S4) located in the interval between WGGC6892 and WGGC5746 were designed. These markers were then used to genotype Xiaobaidong, CC, and the 190 members of the $F_{2}$ population. Among the SSR markers and cross intron-spanning markers developed, four markers were closely linked to $m l x b d$ (Supplementary Fig. S3). Primer sequences for markers closely linked with $m l x b d$ are shown in Table 2.

The closest markers to mlxbd were 7BLSSR49 and WGGC5746, with genetic distances of $0.4 \mathrm{cM}$ and $0.3 \mathrm{cM}$, respectively (Fig. 1). These flanking markers narrowed the genomic region containing $m l x b d$ to a region of $63.40 \mathrm{~kb}$ of the Chinese Spring reference genome and $0.29 \mathrm{Mb}$ on chromosome 7BL of the Zavitan reference genome.

Comparative genomic analyses of the mlxbd interval on chromosome 7BL. The $m l x b d$ locus was previously mapped to a $11.7 \mathrm{cM}$ genetic interval on chromosome 7BL, between SSR markers Xgwm1267 and Xgwm577 (Xue et al. 2009b). Because the previously delimited region was too large, we screened the reported markers ( $\mathrm{Fu}$ et al. 2017; Hu et al. 2008; Huang et al. 2003; Nematollahi et al. 2008; Xie et al. 2017; Xue et al. 2009b) for the target region on chromosome $7 \mathrm{BL}$ and then performed comparative genomic analyses to determine collinear relationships. The base sequences associated with the $m l x b d$-flanking markers WGGC6892 and WGGC5746 were then positioned in the Chinese Spring reference genome. This region spanned a physical interval of about $0.89 \mathrm{Mb}$ (TraesCS7B01G440500 to TraesCS7B01G442200, 706,046,257 to $706,977,079 \mathrm{bp)}$ on the Chinese Spring chromosome 7BL. It displayed a collinear relationship with Zavitan in a $0.78 \mathrm{Mb}$ (TRIDC7BG069560 to TRIDC7BG069740, $712,797,599$ to $713,611,507 \mathrm{bp}$ ) genomic region on chromosome 7BL, a $0.38 \mathrm{Mb}$ (HORVU7HrlG116300.1 to HORVU7HrlG116510.1,

Table 4. (Continued from previous page)

\begin{tabular}{|c|c|c|c|c|c|c|c|c|c|c|c|c|}
\hline \multicolumn{13}{|c|}{ Marker ${ }^{a}$} \\
\hline $\begin{array}{c}7 B L C O S- \\
9\end{array}$ & $\begin{array}{c}7 B L S S R- \\
40\end{array}$ & $\begin{array}{c}7 B L S S R- \\
49\end{array}$ & WGGC5746 & WGGC891 & $\begin{array}{c}\text { 7BLSSR- } \\
17\end{array}$ & Xmp1158 & Xтр1203 & Xgwm577 & $\begin{array}{c}\text { 7BLSSR- } \\
3\end{array}$ & $\begin{array}{c}7 B L S S R- \\
2\end{array}$ & Хтр1179 & $\begin{array}{c}7 B L S S R- \\
6\end{array}$ \\
\hline$\Delta$ & $\Delta$ & $\Delta$ & $\Delta$ & $\Delta$ & $\Delta$ & $\boldsymbol{\Delta}$ & $\Delta$ & $\Delta$ & $\boldsymbol{\Delta}$ & $\Delta$ & $\Delta$ & $\Delta$ \\
\hline$\Delta$ & - & - & - & - & $\Delta$ & - & - & - & - & - & - & - \\
\hline - & $\Delta$ & $\Delta$ & $\Delta$ & $\Delta$ & $\Delta$ & - & - & $\Delta$ & $\Delta$ & $\Delta$ & - & - \\
\hline 口 & 口 & $\square$ & $\square$ & $\square$ & $\square$ & $\square$ & $\square$ & 口 & $\square$ & $\square$ & $\square$ & - \\
\hline 口 & 口 & $\square$ & 口 & 口 & $\square$ & $\square$ & $\square$ & $\square$ & $\square$ & $\square$ & $\square$ & $\square$ \\
\hline 口 & $\square$ & $\square$ & 口 & 口 & $\square$ & $\square$ & $\square$ & 口 & $\square$ & $\square$ & $\square$ & $\square$ \\
\hline 口 & 口 & $\square$ & 口 & 口 & 口 & 口 & $\square$ & 口 & 口 & 口 & 口 & 口 \\
\hline 口 & $\square$ & $\square$ & 口 & 口 & 口 & $\square$ & 口 & 口 & 口 & 口 & - & - \\
\hline$\square$ & $\square$ & 口 & $\square$ & $\square$ & $\square$ & $\square$ & $\square$ & $\square$ & $\square$ & 0 & 0 & 0 \\
\hline 口 & $\square$ & $\square$ & 口 & 口 & 口 & $\square$ & 口 & 口 & - & - & - & - \\
\hline$\square$ & $\square$ & $\square$ & $\square$ & $\square$ & - & - & - & - & - & - & - & - \\
\hline 口 & $\square$ & $\square$ & $\square$ & $\square$ & $\Delta$ & - & - & $\square$ & - & - & - & - \\
\hline
\end{tabular}


$643,220,163$ to $643,614,781 \mathrm{bp})$ genomic region on barley chromosome $7 \mathrm{H}$, a $59.00 \mathrm{~kb}$ (Bradilg30277.1 to Bradilg30330.1, $25,657,742$ to $25,718,153 \mathrm{bp}$ ) genomic region on Brachypodium chromosome 1L, a $17.89 \mathrm{~kb}$ (LOC_OsO6g43170.1 to LOC_ OsO6g43210.1, 25,949,545 to $25,967,860 \mathrm{bp})$ genomic region on rice chromosome 6, and a $49.82 \mathrm{~kb}$ (Sb10g025010.1 to Sb10g025050.1, $54,186,829$ to $54,237,841 \mathrm{bp}$ ) genomic region on sorghum chromosome 10 (Fig. 2, Table 3, Supplementary Table S5).

Within these regions, 18 of 28 predicted Chinese Spring genes were found to be orthologous to 14 of 19 predicted wild emmer genes, 9 of 22 predicted barley genes, 3 of 7 predicted Brachypodium genes, 3 of 5 predicted rice genes, and 3 of 5 predicted sorghum genes (Fig. 2, Table 3, Supplementary Table S5), suggesting that there is some level of microcollinearity in these genomic regions between these species. Chinese Spring genes have high microcollinearity with wild emmer genes and barley genes, but they have a low level of microcollinearity with Brachypodium, rice, and sorghum genes in these genomic regions. Three genes (TraesCS7B01G440800, TraesCS7B01G441600, and TraesCS7B01G441700) that encode proteins with nucleotide binding site (NBS)-leucine rich repeat (LRR) domains were identified in this collinear genomic region (Fig. 2, Table 3, Supplementary Table S5).

Validation of markers flanking $m \boldsymbol{l} \boldsymbol{x} \boldsymbol{b} \boldsymbol{d}$ for the marker-assisted selection of $P \boldsymbol{m}$ resistance genes located on chromosome 7BL. To evaluate the potential use of markers linked with $m l x b d$ in markerassisted selection (MAS), 23 markers were used to identify 11 landraces with known $P m$ resistance genes on chromosome 7BL (Hsam et al. 2001; Hu et al. 2008; Huang et al. 2000b; Xue et al. 2009b; Zhou et al. 2005). The genotype statistics resulting from these tests are shown in Table 4 and Figure 3 . As demonstrated by these results, no marker could completely distinguish between all 11 landraces. Markers WGGC5746, WGGC891, 7BLSSR-40, 7BLSSR-49, $7 B L C O S-8$, and $7 B L C O S-9$, which were closely linked to $m l x b d$, had the same haplotype for the $P m$ resistance genes in nine landraces (Fuzhuang 30, Xiaobaidong, Shangeda, Mangmai, Youbailan, Baiyouyantiao, Hongquangmang, Mazhamai, and Bensanyuehuang) (Table 4). In addition, the haplotypes consisting of 23 markers of Xiaobaidong ( $m l x b d)$, Shangeda (PmSGD), and Mangmai $(\mathrm{mlmm})$ were similar. Therefore, the six mlxbd-associated markers (WGGC5746, WGGC891, 7BLSSR-40, 7BLSSR-49, 7BLCOS-8, and $7 B L C O S-9)$ could be used as diagnostic markers for mlxbd and other Pm resistance genes in landraces Fuzhuang 30, Shangeda, Mangmai, Bensanyuehuang, Youbailan, Mazhamai, Baiyouyantiao, and Hongquangmang. However, these markers could not distinguish these Pm resistance genes.

\section{Discussion}

We mapped the powdery mildew resistance gene in Xiaobaidong on chromosome $7 \mathrm{BL}$ by using an $\mathrm{F}_{2}$ segregating population derived from a reciprocal cross between Xiaobaidong (resistant) and CC

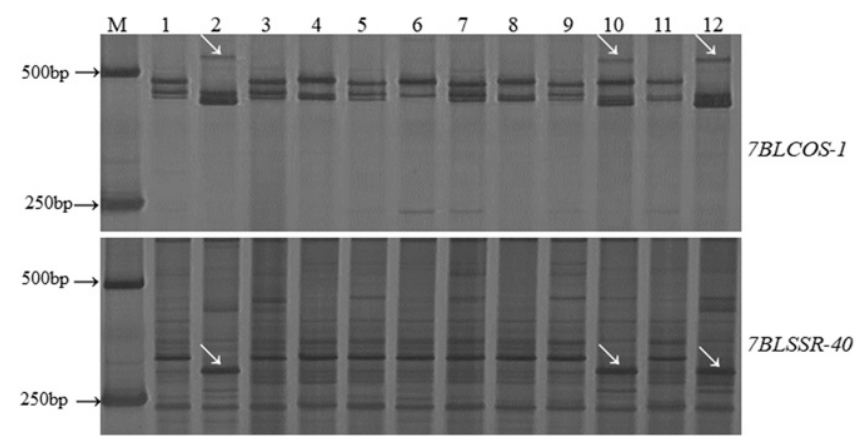

Fig. 3. The results of the tests of the 11 wheat landraces with known $P m$ resistance genes and the susceptible control cultivar Chancellor (CC, without any $P m$ resistance gene) using the markers 7BLCOS-1 and 7BLSSR-40. M, DS2000; 1, Xiaobaidong (m/xbd); 2, CC (without Pm resistance genes); 3 , Fuzhuang $30(P m 5 e)$; 4, Bensanyuehuang $(P m B S Y H) ; 5$, Shangeda (PmSGD); 6, Youbailan (PmYBL); 7, Mangmai $(\mathrm{m} / \mathrm{mm}) ;$, Mazhamai $(\mathrm{m} / \mathrm{mz}) ; 9$, Baiyouyantiao (PmBYYT); 10, Aquila $(P m 5 b)$; 11, Hongquangmang $(P m H)$; and 12, Hope $\times \mathrm{CC}(P m 5 a)$. The white arrows indicate polymorphic fragments. (susceptible) (Xue et al. 2009b). In this study, by using newly designed markers we mapped $m l x b d$ to a $0.7 \mathrm{cM}$ genetic interval between the markers $7 B L S S R-49$ (706,745,365 bp) and WGGC5746 $(706,810,285 \mathrm{bp})$ that spanned a physical distance of $63.40 \mathrm{~kb}$. PmTm4 was previously located between the markers WGGC5746 (706,810,285 bp) and WGGC6892 (706,160,834 bp) on chromosome 7BL based on comparative genomics (Xie et al. 2017). Xmp10311 (704,231,122 bp) and Xmp1158 (708,436,262 bp) were previously identified as the flanking markers of $P m H Y M$ (Fu et al. 2017), and we found that markers Xmp10311 and Xmp1158 are also closely linked to $m l x b d$, and $m l x b d$ is narrowed to a $4.5 \mathrm{cM}$ physical interval (Fig. 1). It appears that $m l x b d$, PmTm4, and PmHYM are located on the same candidate region of chromosome 7BL. The closest flanking markers of PmSGD were SNP2-57 and SNP2-46, PmBYYT was flanked by $W 7 B L-8$ and $W 7 B L-15$, and the genomic regions ranged from $703,304,495$ to $704,270,050 \mathrm{bp}$ and $713,290,626$ to $718,471,448 \mathrm{bp}$, respectively (Xu et al. 2018a, b). Therefore, it was found that the genomic region containing $m l x b d$ was different from those containing PmSGD and PmBYYT.

In this study, marker $W G G C 5746$, which is closely linked to $m l x b d$, targeted gene TraesCS7B01G441600 with a genetic distance of $0.3 \mathrm{cM}$ from $m l x b d$ (Fig. 1, Table 3). Therefore, the gene TraesCS7B01G441600 may not be a candidate gene for $m l x b d$. While analyzing the cloned sequences of the $P m$ resistance genes (Pm2, Pm3, Pm8, Pm17, Pm21, Pm38, and Pm60) of wheat, we found that these genes harbored conserved domains, such as the NBS and LRR domains (Hurni et al. 2014; Krattinger et al 2009; Sánchez-Martín et al. 2016; Singh et al. 2018; Xing et al. 2018; Yahiaoui et al. 2006; Zou et al. 2018). However, TraesCS7B01G441500 is functionally annotated as fructose-1, 6-diphosphate. In addition, Bgt isolate E09 is virulent to Chinese Spring (Tosa et al. 1988) but not to Xiaobaidong. Therefore, Chinese Spring may not contain $m l x b d$. The target gene can be found only in Xiaobaidong by constructing the bacterial artificial chromosome library, exon trapping, or resequencing.

Previous allelism tests of $\mathrm{F}_{3}$ families from Xiaobaidong $(\mathrm{mlxbd}) \times$ Selpek $(P m 5 a)$ and Hope $(P m 5 a) \times$ Fuzhuang 30 (Pm5e) crosses found that $m l x b d$ and Pm5e may be allelic genes closely linked with Pm5a rather than the allelic genes of Pm5 (Huang et al. 2000b). Xu et al. (2018a) used $\mathrm{F}_{2}$ plants of the cross Baiyouyantiao $(P m B Y Y T) \times$ Xiaobaidong $(m l x b d)$ in allelism tests that showed that $P m B Y Y T$ may be allelic or linked to $m l x b d$. To examine the relationships between PmHYM, Pm5e, and $m l x b d$, Fu et al. (2017) performed reciprocal crosses between Hongyoumai (PmHYM) and Fuzhuang 30 (Pm5e), as well as between Hongyoumai (PmHYM) and Xiaobaidong $(m l x b d)$, and based on analyses of the $\mathrm{F}_{2}$ individuals it was demonstrated that PmHYM, Pm5e, and $m l x b d$ were alleles at the same locus. Dahongtou is a wheat landrace. Qie et al. (2019) analyzed $F_{1}$ and $F_{2}$ plants of Dahongtou $\times$ Fuzhuang 30 and Dahongtou $\times$ Xiaobaidong, and their results indicated that $p m D H T, P m 5 e$, and $m l x b d$ were allelic or tightly linked. Therefore, pmDHT, PmBYYT, PmHYM, Pm5e, and $m l x b d$ may be allelic.

The powdery mildew resistance spectrum of Hongyoumai, Fuzhuang 30, and Xiaobaidong showed that these wheat genotypes had differential reactions to Bgt isolates (Xu et al. 2018b). In addition, the reaction patterns of Xiaobaidong and Tangmai 4 to Bgt isolates were found to be the same (Xue et al. 2009a), whereas the study of $\mathrm{Xu}$ et al. (2018b) showed that these two cultivars reacted differently. Therefore, based on the above genomic location allelism comparisons, it was speculated that $m l x b d$ and other resistance genes (PmTm4, pmDHT, PmSGD, PmHYM, PmBYYT, and Pm5e) may be multiple alleles of the same locus or a resistance gene cluster, but at least one of these is a different gene from the others. After the Pm5 locus is cloned, we will know whether they are the same gene or different alleles, such as the resistance alleles at $P m 3$ locus (Yahiaoui et al. 2004, 2009).

Chinese Spring genes have high microcollinearity with wild emmer genes and barley genes in the target genomic regions. However, Chinese Spring genes have a low level of microcollinearity with $\mathrm{Bra}$ chypodium, rice, and sorghum genes in the target genomic regions. 
This could be because the greater rearrangement in this chromosome region leads to a lower microcollinearity (International Brachypodium Initiative 2010).

In the present study, the annotation of resistance-related genes with NBS-LRR domains was predicted in the target genomic region. Within the target genomic region containing $m l x b d, 3$ of the 28 genes predicted in the T. aestivum cultivar Chinese Spring Chr. 7BL genome were found to be collinear with 3 of 19 genes in Triticum dicoccoides cultivar Zavitan Chr. 7BL and 3 of 22 genes in Hordeum vulgare L. Chr. $7 \mathrm{H}$ (Fig. 2). One small-scale inversion occurred in Brachypodium (from BRADIIG30310 to BRADIIG30330) in comparison with the conserved collinearity between Chinese Spring and Zavitan. Yan et al. (2003) used the strongly microcollinear region of rice and wheat to successfully complete the map-based cloning of the wheat vernalization gene Vrn1. Xing et al. (2018) performed the map-based cloning of the Pm21 gene based on microcollinear comparisons with Dasypyrum villosum 6VS, wheat 6AS, 6BS, and 6DS, Brachypodium chromosome 3, and rice chromosome 2. The collinear regions of $m l x b d$ in the Brachypodium genomic database may have produced many rearrangements, as was concluded by Xie et al. (2017).

The use of MAS can effectively increase the bias proportion of traditional selective breeding. However, the success or failure of MAS-based breeding is closely related to the correlations between the molecular markers used and the genes of interest, as well as the stability of the genetic background of the traits of interest (Francia et al. 2005). In the present study, cultivar CC (without any Pm resistance gene) has the same haplotype as Hope $\times \mathrm{CC}(\mathrm{Pm} 5 a)$ and Aquila $(P m 5 b)$ plants for 23 closely linked markers (Fig. 3, Table 4). Combined with the results of the studies of Fu et al. (2017) and Xu et al. (2018a) of resistance reactions for Hope $\times \mathrm{CC}(\mathrm{Pm} 5 \mathrm{a})$ and Aquila $(P m 5 b)$ plants, this suggests that the Hope $\times \mathrm{CC}(P m 5 a)$ and Aquila $(P m 5 b)$ cultivars may have lost most of their resistance to Bgt isolates. Using MAS for Pm resistance genes has resulted in great improvements to selective plant breeding. Pyramiding the genes of cultivars and landraces with multiple $P m$ resistance genes will improve the durability of plant resistance to powdery mildew (Mwale et al. 2017). A total of 23 SSR markers closely linked to $m l x b d$ were tested in 11 landraces with known Pm resistance genes in this study. Among these, the closely linked markers identified as being within $5.0 \mathrm{cM}$ of mlxbd (WGGC5746, WGGC891, 7BLSSR-40, 7BLSSR$49,7 B L C O S-8$, and $7 B L C O S-9)$ will enable the effective pyramiding of multiple resistance genes from different landraces for the transfer of resistance genes. However, these markers could not distinguish these $P m$ resistance genes from landraces. The reason may be that the target chromosome region of the 11 wheat landraces is relatively conservative, with less genetic variation, or resistance genes in these wheat landraces may be the same one. Therefore, only when $m l x b d$ and Pm5 genes are cloned, corresponding functional markers can be developed for MAS. Notably, the stripe rust resistance genes YrZH84 (Li et al. 2006), $\operatorname{YrC591}$ (Li et al. 2009), Yr52 (Ren et al. 2012), Yr59 (Zhou et al. 2014), and Yrsuj (Lan et al. 2015) and the leaf rust (Lr) resistance genes $\operatorname{Lr68}$ (Herrera-Foessel et al. 2012) and LrFun (Xing et al. 2014) were also located on the distal bin of chromosome 7BL-10. Therefore, the closely linked markers of the Pm5 locus could also be used for MAS, which would be convenient to breeding programs.

In recent years, the emergence of technologies such as specificlocus amplified fragment sequencing combined with BSA (Yin et al. 2018), RNA-Seq combined with BSA (Wu et al. 2018; Xu et al. 2018b), and the wheat 90K SNP array (Xu et al. 2018a) can quickly locate candidate intervals of a target gene. Therefore, these approaches have led to their universal application in wheat disease resistance research. Furthermore, the sequencing of the entire genome of wild tetraploid and hexaploid wheat (Chinese Spring) has been completed (Avni et al. 2017; Zimin et al. 2017), which will promote the further study of genes of interest to disease resistance, including the fine mapping and map-based cloning of such genes (Wu et al. 2018; Xing et al. 2018; Zou et al. 2018).

\section{Literature Cited}

Avni, R., Nave, M., Barad, O., Baruch, K., Twardziok, S. O., Gundlach, H., Hale, I., Mascher, M., Spannagl, M., Wiebe, K., Jordan, K. W., Golan, G., Deek, J., Benzvi, B., Benzvi, G., Himmelbach, A., Maclachlan, R., Sharpe, A. G., Fritz, A. K., Bendavid, R., Budak, H., Fahima, T., Korol, A. B., Faris, J. D., Hernandez, A. G., Mikel, M. A., Levy, A. A., Steffenson, B. J., Maccaferri, M., Tuberosa, R., Cattivelli, L., Faccioli, P., Ceriotti, A., Kashkush, K., Pourkheirandish, M., Komatsuda, T., Eilam, T., Sela, H., Sharon, A., Ohad, N., Chamovitz, D. A., Mayer, K. F. X., Stein, N., Ronen, G., Peleg, Z., Pozniak, C. J., Akhunov, E., and Distelfeld, A. 2017. Wild emmer genome architecture and diversity elucidate wheat evolution and domestication. Science 357:93-97.

Francia, E., Tacconi, G., Crosatti, C., Barabaschi, D., Bulgarelli, D., Aglio, E. D., and Vale, G. 2005. Marker assisted selection in crop plants. Plant Cell Tissue Organ Cult. 82:317-342.

Fu, B. S., Zhang, Z. L., Zhang, Q. F., Wu, X. Y., Wu, J. Z., and Cai, S. B. 2017. Identification and mapping of a new powdery mildew resistance allele in the Chinese wheat landrace Hongyoumai. Mol. Breed. 37:133-142.

Hao, Y. F., Liu, A. F., Wang, Y. H., Feng, D. S., Gao, J. R., Li, X. F., Liu, S. B., and Wang, H. G. 2008. Pm23: a new allele of Pm4 located on chromosome 2AL in wheat. Theor. Appl. Genet. 117:1205-1212.

Herrera-Foessel, S. A., Singh, R. P., Huerta-Espino, J., Rosewarne, G. M., Periyannan, S. K., Viccars, L., Calvo-Salazar, V., Lan, C., and Lagudah, E. S. 2012. Lr68: a new gene conferring slow rusting resistance to leaf rust in wheat. Theor. Appl. Genet. 124:1475-1486.

Hsam, S. L., Huang, X. Q., and Zeller, F. J. 2001. Chromosomal location of genes for resistance to powdery mildew in common wheat (Triticum aestivum $\mathrm{L}$. em Thell.) 6. Alleles at the Pm5 locus. Theor. Appl. Genet. 102:127-133.

Hsam, S. L. K., Huang, X. Q., Ernst, F., Hartl, L., and Zeller, F. J. 1998. Chromosomal location of genes for resistance to powdery mildew in common wheat (Triticum aestivum L. em Thell.). 5. alleles at the Pml locus. Theor. Appl. Genet. 96:1129-1134.

Hu, T. Z., Li, H. J., Xie, C. J., You, M. S., Yang, Z. M., Sun, Q. X., and Liu, Z. Y. 2008. Molecular mapping and chromosomal location of powdery mildew resistance gene in wheat cultivar Tangmai 4. Acta Agron. Sin. 34:1193-1198.

Huang, X. Q., Hsam, S. L. K., and Zeller, F. J. 2000b. Chromosomal location of powdery mildew resistance genes in Chinese wheat (Triticum aestivum $\mathrm{L}$. em. Thell.) landraces Xiaobaidong and Fuzhuang 30. J. Genet. Breed. 54: 311-317.

Huang, X. Q., Hsam, S. L. K., and Zeller, F. J. 2002. Chromosomal location of genes for resistance to powdery mildew in Chinese wheat lines Jieyan 94-1-1 and Siyan 94-1-2. Hereditas 136:212-218.x

Huang, X. Q., Hsam, S. L. K., Zeller, F. J., Wenzel, G., and Mohler, V. 2000a. Molecular mapping of the wheat powdery mildew resistance gene Pm24 and marker validation for molecular breeding. Theor. Appl. Genet. 101:407-414.

Huang, X. Q., Wang, L. X., Xu, M. X., and Roder, M. S. 2003. Microsatellite mapping of the powdery mildew resistance gene Pm5e in common wheat (Triticum aestivum L.). Theor. Appl. Genet. 106:858-865.

Hurni, S., Brunner, S., Stirnweis, D., Herren, G., Peditto, D., McIntosh, R. A., and Keller, B. 2014. The powdery mildew resistance gene $P m 8$ derived from rye is suppressed by its wheat ortholog Pm3. Plant J. 79:904-913.

International Brachypodium Initiative. 2010. Genome sequencing and analysis of the model grass Brachypodium distachyon. Nature 463:763-768.

Krattinger, S. G., Lagudah, S. E., Spielmeyer, W., Singh, R. P., Huertaespino, J., Mcfadden, H. G., Bossolini, E., Selter, L. L., and Keller, B. 2009. A putative $\mathrm{ABC}$ transporter confers durable resistance to multiple fungal pathogens in wheat. Science 323:1360-1363.

Lan, C. X., Zhang, Y. L., Herrera-Foessel, S. A., Basnet, B. R., Huerta-Espino, J., Lagudah, E. S., and Singh, R. P. 2015. Identification and characterization of pleiotropic and co-located resistance loci to leaf rust and stripe rust in bread wheat cultivar Sujata. Theor. Appl. Genet. 128:549-561.

Li, G. Q., Cowger, C., Wang, X. W., Carver, B. F., and Xu, X. Y. 2019. Characterization of Pm65, a new powdery mildew resistance gene on chromosome 2AL of a facultative wheat cultivar. Theor. Appl. Genet. 132: 2625-2632.

Li, Y., Niu, Y. C., and Chen, X. M. 2009. Mapping a stripe rust resistance gene YrC591 in wheat variety C591 with SSR and AFLP markers. Theor. Appl. Genet. 118:339-346.

Li, Z. F., Zheng, T. C., He, Z. H., Li, G. Q., Xu, S. C., Li, X. P., Yang, G. Y., Singh, R. P., and Xia, X. C. 2006. Molecular tagging of stripe rust resistance gene YrZH84 in Chinese wheat line Zhou 8425B. Theor. Appl. Genet. 112:1098-1103.

Liu, R. H., and Meng, J. L. 2003. MapDraw: a Microsoft Excel macro for drawing genetic linkage maps based on given genetic linkage data. Heraditas 25: 317-321.

Menardo, F., Praz, C. R., Wyder, S., Bendavid, R., Bourras, S., Matsumae, H., Mcnally, K. E., Parlange, F., Riba, A., Roffler, S., Schaefer, L. K., Shimizu, K. K., Valenti, L., Zbinden, H., Wicker, T., and Keller, B. 2016. Hybridization of powdery mildew strains gives rise to pathogens on novel agricultural crop species. Nat. Genet. 48:201-205.

Mwale, V. M., Tang, X. L., and Chilembwe, E. 2017. Molecular detection of disease resistance genes to powdery mildew (Blumeria graminis f. sp. tritici) in wheat (Triticum aestivum) cultivars. Afr. J. Biotechnol. 16:22-31. 
Nematollahi, G., Mohler, V., Wenzel, G., Zeller, F. J., and Hsam, S. L. K. 2008. Microsatellite mapping of powdery mildew resistance allele Pm5d from common wheat line IGV1-455. Euphytica 159:307-313.

Qie, Y. M., Sheng, Y., Xu, H. X., Jin, Y. L., Ma, F. F., Li, L. H., Li, X. Q., and An, D. G. 2019. Identification of a new powdery mildew resistance gene $p m D H T$ at or closely linked to the Pm5 locus in the Chinese wheat landrace Dahongtou. Plant Dis. 103:2645-2651.

Ren, R. S., Wang, M. N., Chen, X. M., and Zhang, Z. J. 2012. Characterization and molecular mapping of $\mathrm{Yr} 52$ for high-temperature adult-plant resistance to stripe rust in spring wheat germplasm PI 183527. Theor. Appl. Genet. 125:847-857.

Saghai-Maroof, M. A., Soliman, K. M., Jorgensen, R. A., and Allard, R. W. 1984. Ribosomal DNA spacer-length polymorphisms in barley: Mendelian inheritance, chromosomal location, and population dynamics. Proc. Natl. Acad. Sci. 81:8014-8018.

Sánchez-Martín, J., Steuernagel, B., Ghosh, S., Herren, G., Hurni, S., Adamski, N. M., Vrana, J., Kubalakova, M., Krattinger, S. G., Wicker, T., Doležel, J., Keller, B., and Wulff, B. B. H. 2016. Rapid gene isolation in barley and wheat by mutant chromosome sequencing. Genome Biol. 17:221.

Sheng, B. 1988. Grades of resistance to powdery mildew classified by different phenotypes of response in the seeding stage of wheat. Plant Prot. 1:49.

Singh, S. P., Hurni, S., Ruinelli, M., Brunner, S., Sanchez-Martin, J., Krukowski, P., Peditto, D., Buchmann, G., Zbinden, H., and Keller, B. 2018. Evolutionary divergence of the rye $P m 17$ and $P m 8$ resistance genes reveals ancient diversity. Plant Mol. Biol. 98:249-260.

Singrün, C., Hsam, S. L. K., Hartl, L., Zeller, F. J., and Mohler, V. 2003. Powdery mildew resistance gene Pm22 in cultivar Virest is a member of the complex Pm1 locus in common wheat (Triticum aestivum L. em Thell.). Theor. Appl. Genet. 106:1420-1424.

Sun, H. G., Hu, J. H., Song, W., Qiu, D., Cui, L., Wu, P. P., Zhang, H. J., and Liu, H. W. 2018. Pm61: a recessive gene for resistance to powdery mildew in wheat landrace Xuxusanyuehuang identified by comparative genomics analysis. Theor. Appl. Genet. 131:2085-2097.

Tan, C. C., Li, G. Q., Cowger, C., Carver, B. F., and Xu, X. Y. 2018. Characterization of Pm59, a novel powdery mildew resistance gene in Afghanistan wheat landrace PI 181356. Theor. Appl. Genet. 131:1145-1152.

Tan, C. C., Li, G. Q., Cowger, C., Carver, B. F., and Xu, X. Y. 2019. Characterization of Pm63, a powdery mildew resistance gene in Iranian landrace PI 628024. Theor. Appl. Genet. 132:1137-1144.

Tosa, Y., Tokunaga, H., and Ogura, H. 1988. Identification of a gene for resistance to wheat grass powdery mildew fungus in the common wheat cultivar Chinese Spring. Genome 30:612-614.

Ullah, K. N., Li, N., Shen, T., Wang, P. S., Tang, W. B., Ma, S. W., Zhang, Z. M., Jia, H. Y., Kong, Z. X., and Ma, Z. Q. 2018. Fine mapping of powdery mildew resistance gene Pm4e in bread wheat (Triticum aestivum L.). Planta 248: 1319-1328.

Wu, P. P., Xie, J. Z., Hu, J. H., Qiu, D., Liu, Z. Y., Li, J. T., Li, M. M., Zhang, H. J., Yang, L., Liu, H. W., Zhou, Y., Zhang, Z. J., and Li, H. J. 2018. Development of molecular markers linked to powdery mildew resistance gene $P m 4 b$ by combining SNP discovery from transcriptome sequencing data with bulked segregant analysis (BSR-Seq) in wheat. Front. Plant Sci. 9:95.

Xiao, M. G., Song, F. J., Jiao, J. F., Wang, X. M., Xu, H. X., and Li, H. J. 2013. Identification of the gene Pm47 on chromosome 7BS conferring resistance to powdery mildew in the Chinese wheat landrace Hongyanglazi. Theor. Appl. Genet. 126:1397-1403.

Xie, J. Z., Wang, L. L., Wang, Y., Zhang, H. Z., Zhou, S. H., Wu, Q. H., Chen, Y. X., Wang, Z. Z., Wang, G. X., Zhang, D. Y., Zhang, Y., Hu, T. Z., and Liu, Z. Y. 2017. Fine mapping of powdery mildew resistance gene PmTm4 in wheat using comparative genomics. J. Integr. Agric. 16:540-550.

Xie, W. L., BenDavid, R., Zeng, B., Dinoor, A., Xie, C. J., Sun, Q. X., Röder, M. S., Fahoum, A., and Fahima, T. 2011. Suppressed recombination rate in 6VS/6AL translocation region carrying the Pm21 locus introgressed from Haynaldia villosa into hexaploid wheat. Mol. Breed. 29:399-412.

Xing, L. F., Wang, C. F., Xia, X. C., He, Z. H., Chen, W. Q., Liu, T. G., Li, Z. F., and Liu, D. Q. 2014. Molecular mapping of leaf rust resistance gene LrFun in Romanian wheat line Fundulea 900. Mol. Breed. 33:931-937.

Xing, L. P., Hu, P., Liu, J. Q., Witek, K., Zhou, S., Xu, J. F., Zhou, W. H., Gao, L., Huang, Z. P., Zhang, R. Q., Wang, X. E., Chen, P. D., Wang, H. Y., Jones,
J. D. G., Karafiátová, M., Vrána, J., Bartoš, J., Doležel, J., Tian, Y. C., Wu, Y. F., and Cao, A. Z. 2018. Pm21 from Haynaldia villosa encodes a CCNBS-LRR that confers powdery mildew resistance in wheat. Mol. Plant 11 874-878.

Xu, H. X., Yi, Y. J., Ma, P. T., Qie, Y. M., Fu, X. Y., Xu, Y. F., Zhang, X. T., and An, D. G. 2015. Molecular tagging of a new broad-spectrum powdery mildew resistance allele $P m 2 c$ in Chinese wheat landrace Niaomai. Theor. Appl. Genet. 128:2077-2084

Xu, X. D., Feng, J., Fan, J. R., Liu, Z. Y., Qiang, L., Zhou, Y. L., and Ma, Z. H. 2018a. Identification of the resistance gene to powdery mildew in Chinese wheat landrace Baiyouyantiao. J. Integr. Agric. 17:37-45.

Xu, X. D., Li, Q., Ma, Z. H., Fan, J. R., and Zhou, Y. L. 2018b. Molecular mapping of powdery mildew resistance gene $P m S G D$ in Chinese wheat landrace Shangeda using RNA-seq with bulk segregant analysis. Mol. Breed. 38:23-34

Xue, F., Duan, X. Y., Zhou, Y. L., and Ji, W. Q. 2009a. Postulation of powdery mildew resistant genes carried in some Chinese wheat landraces and the genetic diversity analysis. J. Tritic.Crops 29:228-235.

Xue, F., Ji, W. Q., Wang, C. Y., Zhang, H., and Yang, B. J. 2012a. High-density mapping and marker development for the powdery mildew resistance gene PmAS846 derived from wild emmer wheat (Triticum turgidum var. dicoccoides) Theor. Appl. Genet. 124:1549-1560.

Xue, F., Wang, C. Y., Li, C., Duan, X. Y., Zhou, Y. L., Zhao, N. J., Wang, Y. J., and Ji, W. Q. 2012b. Molecular mapping of powdery mildew resistance gene in common wheat landrace Baihulu and its allelism with Pm24. Theor. Appl Genet. 125:1425-1432.

Xue, F., Zhai, W. W., Duan, X. Y., Zhou, Y. L., and Ji, W. Q. 2009b. Microsatellite mapping of powdery mildew resistance gene in wheat landrace Xiaobaidong. Acta Agron. Sin. 35:1806-1811.

Yahiaoui, N., Brunner, S., and Keller, B. 2006. Rapid generation of new powdery mildew resistance genes after wheat domestication. Plant J. 47:85-98.

Yahiaoui, N., Kaur, N., and Keller, B. 2009. Independent evolution of functiona $P m 3$ resistance genes in wild tetraploid wheat and domesticated bread wheat Plant J. 57:846-856.

Yahiaoui, N., Srichumpa, P., Dudler, R., and Keller, B. 2004. Genome analysis at different ploidy levels allows cloning of the powdery mildew resistance gene Pm3b from hexaploid wheat. Plant J. 37:528-538.

Yan, L., Loukoianov, A., Tranquilli, G., Helguera, M., Fahima, T., and Dubcovsky, J. 2003. Positional cloning of the wheat vernalization gene VRN1. Proc. Natl. Acad. Sci. 100:6263-6268.

Yin, J. L., Fang, Z. W., Sun, C., Zhang, P., Zhang, X., Lu, C., Wang, S. P., Ma, D. F., and Zhu, Y. X. 2018. Rapid identification of a stripe rust resistant gene in a space-induced wheat mutant using specific locus amplified fragment (SLAF) sequencing. Sci. Rep. 8:3086.

Zhai, W. W., Duan, X. Y., Zhou, Y. L., and Ma, H. Q. 2008. Inheritance of resistance to powdery mildew in four Chinese landraces. Plant Prot. 34 $37-40$

Zhang, D. Y., Zhu, K. Y., Dong, L. L., Liang, Y., Li, G. Q., Fang, T. L., Guo, G. H., Wu, Q. H., Xie, J. Z., Chen, Y. X., Lu, P., Li, M. M., Zhang, H. Z., Wang, Z. Z., Zhang, Y., Sun, Q. X., and Liu, Z. Y. 2019. Wheat powdery mildew resistance gene Pm64 derived from wild emmer (Triticum turgidum var. dicoccoides) is tightly linked in repulsion with stripe rust resistance gene $\operatorname{Yr} 5$. Crop J. doi.org/10.1016/j.cj.2019.03.003

Zhou, R. H., Zhu, Z. D., Kong, X. Y., Huo, N. X., Tian, Q. Z., Li, P., Jin, C. Y., Dong, Y. C., and Jia, J. Z. 2005. Development of wheat near-isogenic lines for powdery mildew resistance. Theor. Appl. Genet. 110:640-648.

Zhou, X., Wang, M., Chen, X., Lu, Y., Kang, Z., and Jing, J. 2014. Identification of Yr59 conferring high-temperature adult-plant resistance to stripe rust in wheat germplasm PI 178759. Theor. Appl. Genet. 127:935-945.

Zhu, T., Liang, C. Z., Meng, Z. G., Li, Y. Y., Wu, Y. Y., Guo, S. D., and Zhang, R. 2017. PrimerServer: a high-throughput primer design and specificity-checking platform. bioRxiv. 181941

Zimin, A. V., Puiu, D., Hall, R., Kingan, S., Clavijo, B., and Salzberg, S. L. 2017. The first near-complete assembly of the hexaploid bread wheat genome, Triticum aestivum. Gigascience 6:1-7.

Zou, S. H., Wang, H., Li, Y. W., Kong, Z. S., and Tang, D. Z. 2018. The NB-LRR gene Pm60 confers powdery mildew resistance in wheat. New Phytol. 218 298-309. 